\title{
Vitamin D und postmenopausale Knochengesundheit
}

\author{
Bischoff-Ferrari, Heike A
}

\begin{abstract}
Fractures contribute significantly to morbidity and mortality of postmenopausal women. Among postmenopausal women aged 60 years and older, the mortality-adjusted residual lifetime risk of fracture has been estimated to be 44-65\%. Thus, effective strategies are urgently needed to prevent fractures among postmenopausal women. This review summarizes the available evidence that supports vitamin D3 supplementation at a dose of $800 \mathrm{IU}$ per day as a strategy to reduce falls and fractures, including hip fractures, among postmenopausal women by about $20-30 \%$. This recommendation is supported by the Position Statement on Vitamin D of the International Osteoporosis Foundation, the 2011 World Osteoporosis Day Report, and the US Endocrine Society. Further, this recommendation is supported by the high prevalence of vitamin D deficiency among postmenopausal women. The prevalence of vitamin D deficiency (serum levels below $50 \mathrm{nmol} / \mathrm{l}$ or $20 \mathrm{ng} / \mathrm{ml}$ ) among younger and older postmenopausal women has been found to be about $50 \%$ in many countries around the world, with the highest prevalence $(80 \%)$ in older women with hip fractures. = Knochenfrakturen tragen in signifikantem Ausmaß zu Morbidität und Mortalität in der Postmenopause bei. Schätzungen des mortalitätsadjustierten Frakturrisikos in der verbleibenden Lebenszeit für Frauen im Alter $\geq 60$ liegen zwischen 44 und $65 \%$. Unbedingt notwendig sind also effektive Präventionsstrategien. Im Review-Beitrag wird die verfügbare Evidenz zur Vitamin-D3-Supplementierung (800 I.E. täglich) für eine 20- bis 30\%ige Reduzierung von Sturzereignissen und (Hüft-)Frakturen bei postmenopausalen Frauen zusammengefasst. Diese Empfehlung wird gestützt von Positionspapieren der International Osteoporosis Foundation, des 2011 World Osteoporosis Day Report und der US-amerikanischen Endocrine Society, ferner von der hohen Prävalenz eines Vitamin-D-Mangels bei postmenopausalen Frauen. Die Vitamin-D-Mangel-Prävalenz (Serum-Konzentrationen <50 nmol/l bzw. $20 \mathrm{ng} / \mathrm{ml}$ ) bei jüngeren wie älteren postmenopausalen Frauen wurde in vielen Ländern weltweit mit etwa $50 \%$ angegeben, am höchsten $(80 \%)$ war sie bei älteren Frauen mit Hüftfrakturen.
\end{abstract}

DOI: https://doi.org/10.1007/s00129-015-3727-7

Posted at the Zurich Open Repository and Archive, University of Zurich

ZORA URL: https://doi.org/10.5167/uzh-207569

Journal Article

Published Version

Originally published at:

Bischoff-Ferrari, Heike A (2015). Vitamin D und postmenopausale Knochengesundheit. Der Gynäkologe, 48(S1):16.

DOI: https://doi.org/10.1007/s00129-015-3727-7 
Gynäkologe 2015 · [Suppl 1]: 48:S1-S5 DOI 10.1007/s00129-015-3727-7

Published online: 17 June 2015

(c) Springer-Verlag Berlin Heidelberg 2015

CrossMark

\section{H. Bischoff-Ferrari}

Klinik für Geriatrie, Universitätsspital Zürich, Lehrstuhl Geriatrie und Altersforschung, Zürich, Schweiz

\section{Role of vitamin D in postmenopausal bone health}

\author{
English Version
}

\section{Epidemiology of fractures in postmenopausal women}

After age 75, hip fractures are the most frequent type of fracture. Up to $50 \%$ of postmenopausal women suffering a hip fracture will have permanent functional disability, 15-25\% will require long-term nursing home care, and up to $20 \%$ will die within the first year after the event [1-10]. The exponential increase in hip fractures after age 75 translates into an estimated 1 in 3 women who will have sustained a hip fracture by their ninth decade of life [11].

Similar to hip fractures, the two other most common nonvertebral fractures distal forearm and proximal humerus fractures - show a steep increase with age [12]. A further 1 in 3 women will have a prevalent vertebral fracture at age 80 [13]. Vertebral fractures also cause disability, back pain, [14], and decreased quality of life [15]. Postmenopausal women with a first vertebral fracture have a more than $19 \%$ risk of developing a second vertebral fracture in the subsequent year [16]. Further, they have a 2.5 -fold increased risk for any subsequent fracture [17], and a 2.8 -fold increased mortality rate within the following 10 years [18]. Compared with hip fractures, the epidemiology of vertebral fractures is challenging with less than $30 \%$ of vertebral fractures coming to clinical attention [19].

\section{Vitamin D supplementation and fracture reduction in postmenopausal women}

Vitamin D is essential for bone growth $[20,21]$ and preservation [22], and higher 25-hydroxyvitamin D [25(OH)D] levels are associated with higher bone density in younger and older adults [23]. Moreover, in double-blind randomized controlled trials (RCTs) among adults aged 65 and older, vitamin D supplementation increased bone density and reduced bone loss [24, 25].

Regarding the effect of vitamin D supplementation on fracture risk, the data from several study-level meta-analyses and two pooled individual participantlevel (IPD) analyses are conflicting. While one trial-level meta-analysis of double-blind (RCTs suggested an $18 \%$ reduction of hip fractures and $20 \%$ reduction of any nonvertebral fractures at a received dose of no less than 482 IU vitamin D per day [26], three study-level meta-analyses [27-29] and one pooled IPD analysis [30] of open-design and blinded trials suggested that vitamin $\mathrm{D}$ may have a neutral effect on total fractures [27] or may reduce hip fractures by $7-16 \%$ independent of its dose if combined with calcium supplementation [27-29]. Finally, in the most recent 2012 pooled IPD analysis of 31,022 primarily postmenopausal women enrolled in double-blind RCTs on vitamin D, only an actual intake of 792-2,000 IU per day reduced the risk of fracture, with no benefit seen at a lower dose [31]. At the high intake range (median 800 IU per day), hip fracture risk was reduced by $30 \%$ [31]. The discordant findings may in part be explained by different inclusion criteria of trials with respect to blinding and intake form (oral, injectable), or different accommodations for adherence. A dose-response relationship between vitamin $\mathrm{D}$ and fracture reduction as documented in the 2009 meta-analyses of double-blind RCTs [26] and the 2012 IPD pooled analysis [31] is supported by epidemiologic data showing a significant positive trend between serum $25(\mathrm{OH}) \mathrm{D}$ concentrations and hip bone density [23] and lower extremity strength [32, 33].

Factors that may obscure the benefit of vitamin $\mathrm{D}$ are low adherence to treatment [34], low dose of vitamin $D$, or the use of less potent vitamin $\mathrm{D}_{2}[35,36]$. Furthermore, open-design trials [37] may bias results toward a null effect because participants who know that they have been randomized to the control group may purchase vitamin $\mathrm{D}$ themselves as it is available without prescription.

The inclusion of mixed-quality studies may explain the recent findings and conclusion of the 2014 sequential metaanalysis by Bolland and colleagues [38, 39] that vitamin $D$ may not be effective in fracture reduction. The authors included many studies that had little chance of demonstrating the true potential benefits of vitamin D. In particular, their analysis was based on a great mix of trials with blinded and open designs, follow-up periods that were often too short, administered doses that ranged widely, compliance that ranged widely, and endpoints that ranged from primary to secondary to un-prespecified, and consequently were adjudicated and nonadjudicated. The authors also chose to carry out their sequential meta-analysis with the goal of detecting a $15 \%$ effect threshold for most outcomes and $5 \%$ for mortality. We question this approach, as even

The German version of this article can be found at doi: 10.1007/s00129-015-3723-y. 
small effects carry an enormous benefit if an inexpensive intervention such as vitamin D is implemented broadly. In fact, for vitamin $\mathrm{D}$ plus calcium, the authors themselves document a significant $8 \%$ reduction in total fractures and a significant $16 \%$ reduction in hip fractures. Further, the authors document a significant $4 \%$ reduction in overall mortality with vitamin $\mathrm{D}$ alone or in combination with calcium, which is particularly notable in the context of the limitations of the studies included. A fair question of a clinician may be, „Do I really stop supplementation with vitamin $\mathrm{D}$ when it has a significant reduction of hip fracture by $16 \%$ (in conjunction with calcium) and of mortality by $4 \%$ but not $5 \%$ ?"Notably, on a public health level, a $4 \%$ reduction of mortality generates an enormous population benefit.

\section{Risk factors for vitamin D deficiency}

Most vulnerable to vitamin D deficiency are older adults [40, 41], individuals living in northern latitudes with prolonged winters and thus low UVB exposure [42, 43], obese individuals [44], and individuals of all ages with a dark skin tone [23, $45,46]$. Other risk factors include medical conditions such as malabsorption and the use of anti-epileptic drugs [4].

\section{Optimal 25(OH)D level for fracture prevention in postmenopausal women}

A threshold for optimal serum 25(OH)D concentration and fracture prevention has been addressed in a recent benefit-risk analysis [47]. Based on data from RCTs and their achieved 25(OH)D levels in the treatment group, $75 \mathrm{nmol} / \mathrm{l}$ (30 $\mathrm{ng} / \mathrm{ml}$ ) is suggested as the best point estimate for an optimal threshold of $25(\mathrm{OH}) \mathrm{D}$ for fracture prevention. This threshold is further supported by epidemiologic data for hip bone density in younger and older adults [23], as well as a large bone-biopsy study in which mineralization defects were absent with serum levels of at least $75 \mathrm{nmol} / \mathrm{l}$ [48]. Also, the most recent pooled IPD analysis of double-blind RCTs found that among

Gynäkologe 2015 · [Suppl 1]: 48:S1-S5 DOI 10.1007/s00129-015-3727-7

c) Springer-Verlag Berlin Heidelberg 2015

\section{H. Bischoff-Ferrari}

\section{Role of vitamin D in postmenopausal bone health. English Version}

\section{Abstract}

Fractures contribute significantly to morbidity and mortality of postmenopausal women. Among postmenopausal women aged 60 years and older, the mortality-adjusted residual lifetime risk of fracture has been estimated to be $44-65 \%$. Thus, effective strategies are urgently needed to prevent fractures among postmenopausal women. This review summarizes the available evidence that supports vitamin D3 supplementation at a dose of 800 IU per day as a strategy to reduce falls and fractures, including hip fractures, among postmenopausal women by about $20-30 \%$. This recommendation is supported by the Position Statement on Vitamin D of the International Osteoporosis
Foundation, the 2011 World Osteoporosis Day Report, and the US Endocrine Society. Further, this recommendation is supported by the high prevalence of vitamin $D$ deficiency among postmenopausal women. The prevalence of vitamin $D$ deficiency (serum levels below $50 \mathrm{nmol} / \mathrm{l}$ or $20 \mathrm{ng} / \mathrm{ml}$ ) among younger and older postmenopausal women has been found to be about $50 \%$ in many countries around the world, with the highest prevalence $(80 \%)$ in older women with hip fractures.

Keywords

Menopause · Osteoporosis · Fractures · Fall events.Calcium

\section{Vitamin D und postmenopausale Knochengesundheit. Englische Version}

\section{Zusammenfassung}

Knochenfrakturen tragen in signifikantem Ausmaß zu Morbidität und Mortalität in der Postmenopause bei. Schätzungen des mortalitätsadjustierten Frakturrisikos in der verbleibenden Lebenszeit für Frauen im Alter $\geq 60$ liegen zwischen 44 und $65 \%$. Unbedingt notwendig sind also effektive Präventionsstrategien. Im Review-Beitrag wird die verfügbare Evidenz zur Vitamin-D3-Supplementierung (800 I.E. täglich) für eine 20 - bis $30 \%$ ige Reduzierung von Sturzereignissen und (Hüft-)Frakturen bei postmenopausalen Frauen zusammengefasst. Diese Empfehlung wird gestützt von Positionspapieren der International Osteoporosis Foundation, des
2011 World Osteoporosis Day Report und der US-amerikanischen Endocrine Society, ferner von der hohen Prävalenz eines Vitamin-DMangels bei postmenopausalen Frauen. Die Vitamin-D-Mangel-Prävalenz (SerumKonzentrationen $<50 \mathrm{nmol} / \mathrm{l} \mathrm{bzw.} 20 \mathrm{ng} / \mathrm{ml}$ ) bei jüngeren wie älteren postmenopausalen Frauen wurde in vielen Ländern weltweit mit etwa $50 \%$ angegeben, am höchsten (80\%) war sie bei älteren Frauen mit Hüftfrakturen.

Schlüsselwörter

Menopause - Osteoporose - Frakturen . Sturzereignisse $\cdot$ Kalzium over 4,000 primarily postmenopausal women, fracture risk declined significantly with higher baseline $25(\mathrm{OH}) \mathrm{Ds}$ levels [31]. Comparing individuals with starting levels of less than $30 \mathrm{nmol} / \mathrm{l}$ with those on starting levels of $61 \mathrm{nmol} / \mathrm{l}$ and above, the latter group had a $37 \%$ lower risk of hip fracture and a $31 \%$ lower risk of any nonvertebral fracture [31].

The $25(\mathrm{OH}) \mathrm{D}$ threshold of at least $75 \mathrm{nmol} / \mathrm{l}(30 \mathrm{ng} / \mathrm{ml})$ for optimal fracture prevention is supported by the 2010 IOF position statement on vitamin $\mathrm{D}$ [2] and the 2011 US Endocrine Society Task Force on Vitamin D [4]. By contrast, the 2010 Institute of Medicine recommendations suggest that $50 \mathrm{nmol} / \mathrm{l}$ may be sufficient for bone health in the population, although (1) no single trial that reached $50 \mathrm{nmol} / \mathrm{l}$ in their treatment group achieved fracture reduction, and (2) in their fracture assessment section the IOM report reads that only studies that achieved 25(OH)D levels of at least $75 \mathrm{nmol} / \mathrm{l}$ showed significant fracture reduction [49]. Current intake recommendations of 800 IU vitamin D per day will shift over $97 \%$ of postmenopausal women to at least $50 \mathrm{nmol} / \mathrm{l}$ and about $50 \%$ to $75 \mathrm{nmol} / \mathrm{l}[49,50]$. 


\section{Infobox 1 Key messages}

1. Vitamin D supplementation reduces the risk of fracture; however, this benefit is dose dependent. All recent recommendations support 800 IU vitamin D per day for fracture reduction.

2. Vitamin $D$ reduces fracture risk through both its benefit on bone and its effect on fall reduction.

3. To achieve optimal fracture reduction, a $25(\mathrm{OH}) \mathrm{D}$ threshold of at least $61 \mathrm{nmol} / \mathrm{I}$ and ideally $75 \mathrm{nmol} / \mathrm{l}$ may be warranted.

\section{Vitamin $D$ benefits in fracture prevention and the effect of vitamin D on muscle}

The beneficial effect of vitamin $\mathrm{D}$ on calcium absorption and bone mineral density may not be the only explanation for its protective effect against fractures [26]. In fact, vitamin $\mathrm{D}$ deficiency may cause muscular impairment even before adverse effects on bone occur [51].

Four lines of evidence support the role of vitamin D in musclehealth. First, proximal muscle weakness is a prominent feature of the clinical syndrome of vitamin D deficiency [52]. Clinical findings in vitamin D deficiency myopathy include proximal muscle weakness, diffuse muscle pain, and gait impairments such as a waddling way of walking [53]. Second, the vitamin $\mathrm{D}$ receptor (VDR) is expressed in human muscle tissue [54-56], and VDR activation may promote de novo protein synthesis in muscle [56-58]. Mice lacking the VDR show a skeletal muscle phenotype with smaller and variable muscle fibers and persistence of immature muscle gene expression during adult life $[59,60]$. Third, several observational studies suggest a positive association between 25(OH)D and muscle strength or lower extremity function in older persons [32, 33]. Fourth, vitamin D supplementation increases muscle strength and balance [61, 62], and reduces the risk of falling in community-dwelling individuals [62-64], as well as in institutionalized individuals $[61,65]$, in several doubleblind RCTs summarized in a 2009 metaanalysis [66].

Thus, relevant to fracture prevention in older postmenopausal women, vitamin D supplementation for fall prevention should not be delayed. This suggestion is in line with the Agency for Healthcare Research and Quality (AHRQ) of the US Preventive Services Task Force [67], the 2010 American Geriatric Society/British Geriatric Society Clinical Practice Guideline [68], the 2010 assessment by the IOF [2], and the 2011 Endocrine Society Recommendations, all four of which identified vitamin $\mathrm{D}$ as an effective intervention to prevent falling in older adults.

\section{Amount of vitamin D needed to overcome vitamin D deficiency}

Most healthy adults overcome vitamin D deficiency by reaching $25(\mathrm{OH}) \mathrm{D}$ serum concentrations of about $50 \mathrm{nmol} / \mathrm{l}$ with 600-800 IU vitamin D per day [50,69]. Among healthy postmenopausal white women, a recent multidose comparison suggested that a dose of 1,600 IU per day may be sufficient for $97.5 \%$ of the study population to reach $75 \mathrm{nmol} / 1$ [69]. Notably, however, this dose has not been tested for fracture prevention.

\section{Conclusion}

Postmenopausal women have a high risk of vitamin $\mathrm{D}$ deficiency and vita$\min \mathrm{D}$ is relevant to bone and muscle health, as supported by several lines of evidence summarized in this review article. Meta-analyses of double-blind RCTs provide strong support for vitamin D supplementation at a dose of $800 \mathrm{IU}$ per day in postmenopausal women for fall and fracture prevention.

\section{Corresponding address}

Prof. Dr. med. H. Bischoff-Ferrari

Klinik für Geriatrie, Universitätsspital Zürich, Lehrstuhl Geriatrie und Altersforschung Rämistrasse 100, 8091 Zürich, Schweiz Heike.Bischoff@usz.ch

\section{Compliance with ethical guidelines}

Conflict of interest. Heike Bischoff-Ferrari declares that she has no conflict of interest.
This article does not contain any studies with human participants or animals performed by any of the authors.

\section{References}

1. Nguyen ND, Ahlborg HG, Center JR et al (2007) Residual lifetime risk of fractures in women and men. J Bone Miner Res 12:12

2. Dawson-Hughes B, Mithal A, Bonjour JP et al (2010) IOF position statement: vitamin D recommendations for older adults. Osteoporos Int 21(7):1151-1154

3. Bischoff Ferrari HA (2011) Three steps to unbreakable bones: the 2011 World Osteoporosis Day Report. http://www.iofbonehealth.org//WOD 11/WOD11-Report.pdf. Accessed 3 June 2012

4. Holick MF, Binkley NC, Bischoff-Ferrari HA et al (2011) Evaluation, treatment, and prevention of vitamin d deficiency: an endocrine society clinical practice guideline. J Clin Endocrinol Metab 96(7):1911-1930

5. van Schoor NM, Lips P (2011) Worldwide vitamin D status. Best Pract Res Clin Endocrinol Metab 25(4):671-680

6. Bischoff-Ferrari HA, Can U, Staehelin HB et al (2008) Severe vitamin $D$ deficiency in Swiss hip fracture patients. Bone 42(3):597-602

7. LeBoff MS, Kohlmeier L, Hurwitz S et al (1999) Occult vitamin D deficiency in postmenopausal US women with acute hip fracture. JAMA 281(16):1505-1511

8. Magaziner J, Hawkes W, Hebel JR et al (2000) Recovery from hip fracture in eight areas of function. J Gerontol A Biol Sci Med Sci 55(9):M498-M507

9. Tinetti ME, Williams CS (1997) Falls, injuries due to falls, and the risk of admission to a nursing home. $N$ Engl J Med 337(18):1279-1284

10. Cummings SR, Kelsey JL, Nevitt MC, O'Dowd KJ (1985) Epidemiology of osteoporosis and osteoporotic fractures. Epidemiol Rev 7:178-208

11. Birge SJ, Morrow-Howell N, Proctor EK (1994) Hip fracture. Clin Geriatr Med 10(4):589-609

12. Barrett JA, Baron JA, Karagas MR, Beach ML (1999) Fracture risk in the U.S. Medicare population J Clin Epidemiol 52(3):243-249

13. Nevitt MC, Cummings SR, Stone KL et al (2005) Risk factors for a first-incident radiographic vertebral fracture in women $>$ or $=65$ years of age: the study of osteoporotic fractures. J Bone Miner Res 20(1):131-140

14. Nevitt MC, Ettinger B, Black DM et al (1998) The association of radiographically detected vertebral fractures with back pain and function: a prospective study. Ann Intern Med 128(10):793-800

15. Silverman SL, Minshall ME, Shen W et al (2001) The relationship of health-related quality of life to prevalent and incident vertebral fractures in postmenopausal women with osteoporosis: results from the Multiple Outcomes of Raloxifene Evaluation Study. Arthritis Rheum 44(11):2611-2619

16. Lindsay R, Silverman SL, Cooper C et al (2001) Risk of new vertebral fracture in the year following a fracture. JAMA 285(3):320-323

17. Center JR, BliucD, Nguyen TV, Eisman JA (2007) Risk of subsequent fracture after low-trauma fracture in men and women. JAMA 297(4):387-394

18. Hasserius R, Karlsson MK, Jonsson B et al (2005) Long-Term Morbidity and Mortality After a Clinically Diagnosed Vertebral Fracture in the 
Elderly - a 12- and 22-year Follow-Up of 257 Patients. Calcif Tissue Int 76(4):235-242

19. Cooper C, Melton LJIII (1992) Epidemiology of osteoporosis. Trends Endocrinol Metab 314:224-229

20. Specker BL, Ho ML, Oestreich A et al (1992) Prospective study of vitamin D supplementation and rickets in China. J Pediatr 120(5):733-739

21. Aksnes L, Aarskog D (1982) Plasma concentrations of vitamin $D$ metabolites in puberty: effect of sexual maturation and implications for growth. J Clin Endocrinol Metab 55(1):94-101

22. Smith R, Dent CE (1969) Vitamin D requirements in adults. Clinical and metabolic studies on seven patients with nutritional osteomalacia. Bibl Nutr Dieta 13:44-45

23. Bischoff-Ferrari HA, Dietrich T, Orav EJ, DawsonHughes B (2004) Positive association between 25 hydroxy vitamin D levels and bone mineral density: a population-based study of younger and older adults. Am J Med 116(9):634-639

24. Dawson-Hughes B, Dallal GE, Krall EA et al (1991) Effect of vitamin D supplementation on wintertime and overall bone loss in healthy postmenopausal women. Ann Intern Med 115(7):505-512

25. Ooms ME, Roos JC, Bezemer et al (1995) Prevention of bone loss by vitamin $D$ supplementation in elderly women: a randomized double-blind trial. J Clin Endocrinol Metab 80(4):1052-1058

26. Bischoff-Ferrari HA, Willett WC, Wong JB et al (2009) Prevention of nonvertebral fractures with oral vitamin D and dose dependency: a metaanalysis of randomized controlled trials. Arch Intern Med 169(6):551-561

27. Cranney A, Horsley T, O’Donnell S et al (2007) Effectiveness and safety of vitamin $D$ in relation to bone health. Evid Rep Technol Assess (Full Rep) 158:1-235

28. Boonen S, Lips P, Bouillon R et al (2007) Need for additional calcium to reduce the risk of hip fracture with vitamin $d$ supplementation: evidence from a comparative metaanalysis of randomized controlled trials. J Clin Endocrinol Metab 92(4):1415-1423

29. Avenell A, Gillespie WJ, Gillespie LD, O'Connell D (2009) Vitamin D and vitamin D analogues for preventing fractures associated with involutional and post-menopausal osteoporosis. Cochrane Database Syst Rev 2:CD000227

30. DIPART (2010) Patient level pooled analysis of 68 500 patients from seven major vitamin $D$ fracture trials in US and Europe. BMJ 340:b5463

31. Bischoff-Ferrari HA, Orav EJ, Willett WC et al (2012) A pooled analysis of vitamin $D$ dose requirements for fracture prevention. NEngl J Med 367(1):40-49

32. Bischoff-Ferrari HA, Dietrich T, Orav EJ et al (2004) 25-hydroxyvitamin D concentrations are associated with better lower-extremity function in both active and inactive persons aged $>=60 \mathrm{y}$. Am JClin Nutr 80(3):752-758

33. Wicherts IS, van Schoor NM, Boeke AJ et al (2007) Vitamin D status predicts physical performance and its decline in older persons. J Clin Endocrinol Metab 6:6

34. Grant AM, Avenell A, Campbell MK et al (2005) Oral vitamin D3 and calcium for secondary prevention of low-trauma fractures in elderly people (Randomised Evaluation of Calcium Or vitamin $D, R E C O R D)$ : a randomised placebocontrolled trial. Lancet 365(9471):1621-1628
35. Armas LA, Hollis BW, Heaney RP (2004) Vitamin D2 is much less effective than vitamin D3 in humans. Clin Endocrinol Metab 89(11):5387-5391

36. Houghton LA, Vieth R (2006) The case against ergocalciferol (vitamin D2) as a vitamin supplement. Am JClin Nutr 84(4):694-697

37. Porthouse J, Cockayne S, King C et al (2005) Randomised controlled trial of calcium and supplementation with cholecalciferol (vitamin D3) for prevention of fractures in primary care. BMJ 330(7498):1003

38. Bolland MJ, Grey A, Gamble GD, Reid IR (2014) The effect of vitamin D on skeletal, vascular, or cancer outcomes: a trial sequential meta-analysis. Lancet (online)

39. Bischoff-Ferrari HA, Orav EJ, Willett WC, Dawson-Hughes B (2014) The effect of vitamin D supplementation on skeletal, vascular, or cancer outcomes. Lancet Diabetes Endocrinol 2(5):363-364

40. McKenna MJ (1992) Differences in vitamin D status between countries in young adults and the elderly. Am J Med 93(1):69-77

41. Theiler R, Stahelin HB, Tyndall A et al (1999) Calcidiol, calcitriol and parathyroid hormone serum concentrations in institutionalized and ambulatory elderly in Switzerland. Int J Vitam Nutr Res 69(2):96-105

42. Webb AR, Kline L, Holick MF (1988) Influence of season and latitude on the cutaneous synthesis of vitamin D3: exposure to winter sunlight in Boston and Edmonton will not promote vitamin D3 synthesis in human skin. J Clin Endocrinol Metab 67(2):373-378

43. Dawson-Hughes B, Harris SS, Dallal GE (1997) Plasma calcidiol, season, and serum parathyroid hormone concentrations in healthy elderly men and women. Am JClin Nutr 65(1):67-71

44. Parikh SJ, Edelman M, Uwaifo Gl et al (2004) The relationship between obesity and serum 1,25dihydroxy vitamin $D$ concentrations in healthy adults. JClin Endocrinol Metab 9(3):1196-1199

45. Looker AC, Dawson-Hughes B, Calvo MSetal (2002) Serum 25-hydroxyvitamin D status of adolescents and adults in two seasonal subpopulations from NHANES III. Bone 30(5):771-777

46. Nesby-O'Dell S, Scanlon KS, Cogswell ME et al (2002) Hypovitaminosis D prevalence and determinants among African American and white women of reproductive age: third National Health and Nutrition Examination Survey, 1988-1994. Am JClin Nutr 76(1):187-192

47. Bischoff-Ferrari HA, Shao A, Dawson-Hughes B, Hathcock J, Giovannucci E, Willett WC (2010) Benefit-RiskAssessment of Vitamin D Supplementation. Osteoporos Int 21(7):1121-1132

48. Priemel $M$, von Domarus $C$, Klatte TO et al (2011) Bone mineralization defects and vitamin D deficiency: histomorphometric analysis of iliac crest bone biopsies and circulating 25hydroxyvitamin Din 675 patients. J Bone Miner Res 25(2):305-312

49. IOM (2010) Dietary Reference Ranges for Calcium and Vitamin D. http://www.iom.edu/Reports/ 2010/Dietary-Reference-Intakes-for-Calciumand-Vitamin-D.aspx. Accessed 13 Feb 2012

50. Bischoff-Ferrari HA, Shao A, Dawson-Hughes B et al (2010) Benefit-risk assessment of vitamin D sup plementation. Osteoporos Int 21(7):1121-1132

51. Glerup H, Mikkelsen K, Poulsen L et al (2000) Hypovitaminosis $\mathrm{D}$ myopathy without biochemical signs of osteomalacic bone involvement. Calcif Tissue Int 66(6):419-424

52. Al-Shoha A, Qiu S, Palnitkar S, Rao DS (2009) Osteomalacia with bone marrow fibrosis due to severe vitamin D deficiency after a gastrointestinal bypass operation for severe obesity. Endocr Pract 15(6):528-533

53. Schott GD, Wills MR (1976) Muscle weakness in osteomalacia. Lancet 1(7960):626-629

54. Bischoff-Ferrari HA, Borchers $M$, Gudat $F$ et al (2004) Vitamin D receptor expression in human muscle tissue decreases with age. J Bone Miner Res 19(2):265-269

55. Ceglia L, da Silva Morais M, Park LK et al (2010) Multi-step immunofluorescent analysis of vitamin $D$ receptor loci and myosin heavy chain isoforms in human skeletal muscle. J Mol Histol 41(2-3):137-142

56. Ceglia L, Niramitmahapanya S, da Silva Morais M et al (2013) A randomized study on the effect of vitamin D3 supplementation on skeletal muscle morphology and vitamin D receptor concentration in older women. J Clin Endocrinol Metab 98(12):E1927-E1935

57. Sorensen OH, LundB, Saltin B etal (1979) Myopathy in bone loss of ageing: improvement by treatment with 1 alpha-hydroxycholecalciferol and calcium. Clin Sci (Colch) 56(2):157-161

58. Freedman LP (1999) Transcriptional targets of the vitamin D3 receptor-mediating cell cyclearrestand differentiation. J Nutr 129(2S Suppl):581S-586S

59. Bouillon R, Bischoff-Ferrari H, Willett W (2008) Vitamin D and health: perspectives from mice and man. J Bone Miner Res 28:28

60. Endo I, Inoue D, Mitsui T et al (2003) Deletion of vitamin Dreceptorgene in mice results in abnormal skeletal muscle development with deregulated expression of myoregulatory transcription factors. Endocrinology 144(12):5138-5144

61. BischoffHA, Stahelin HB, Dick W et al (2003) Effects of vitamin Dand calcium supplementation on falls: a randomized controlled trial. J Bone Miner Res 18(2):343-351

62. Pfeifer M, Begerow B, Minne HW et al (2008) Effects of a long-term vitamin $D$ and calcium supplementation on falls and parameters of muscle function in community-dwelling older individuals. Osteoporos Int 16:16

63. Bischoff-Ferrari HA, Orav EJ, Dawson-Hughes B (2006) Effect of cholecalciferol plus calcium on falling in ambulatory older men and women: a 3year randomized controlled trial. Arch Intern Med 166(4):424-430

64. Pfeifer M, Begerow B, Minne HW et al (2000) Effects of a short-term vitamin D and calcium supplementation on body sway and secondary hyperparathyroidism in elderly women. J Bone MinerRes 15(6):1113-1118

65. Broe KE, Chen TC, Weinberg J et al (2007) A higher dose of vitamin d reduces the risk of falls in nursing home residents: a randomized, multiple-dose study. J Am Geriatr Soc 55(2):234-239

66. Bischoff-Ferrari HA, Dawson-Hughes B, Staehelin $\mathrm{HB}$ et al (2009) Fall prevention with supplemental and active forms of vitamin D: a meta-analysis of randomised controlled trials. BMJ 339(1) 339:b3692

67. Michael YL, Whitlock EP, Lin JS et al (2011) Primary care-relevant interventions to prevent falling in older adults: a systematic evidence review for the u.s. Preventive services task force. Ann Intern Med 153(12):815-825 
68. AGS/BGS (2011) AGS/BGS Guidelines on Fall Prevention in older Persons. http://www. patientsafetysolutions.com/docs/February

2011_Updated_Fall_Prevention_Guide-lines.

htm. Accessed 13 Feb 2012

69. Gallagher JC, Sai A, Templin TII, Smith L (2012)

Dose response to vitamin $D$ supplementation in postmenopausal women: a randomized trial. Ann Intern Med 156(6):425-437 
